\title{
Index of Authors
}

\author{
Numerals followed by the letter A refer to \\ Abstracts of Communication read at Meetings for \\ Original Communications of the Nutrition Society
}

Acamovic T \& Brooker JD Biochemistry of plant secondary metabolites and their effects in animals, DOI: 10.1079/PNS2005449, 403.

Adachi J, Sato M, Yoshioka N, Ueno Y, Lin CI, Wong MCY, Preedy VR \& Wiseman $\mathrm{H}$ The protective effect of the isoflavone phyto-oestrogen daidzein against formation of oxysterols in rat liver and brain after acute alcohol dosage, $94 \mathrm{~A}$

Ager L see Dickinson A, 269.

Al-Naimi S, Hampton SM, Richard P, Tzung C \& Morgan LM Postprandial responses to sequential meals in simulated day and night shift workers, 16A.

Aldhaheri A, Henry CJK \& Lightowler HJ The influence of ethnicity on the glycaemic index of foods, 55A.

Allison SP Integrated nutrition, DOI: 10.1079/PNS2005438, 319.

Appleton KM, Hayward RC, Gunnell D, Peters TJ, Rogers PJ, Kessler D \& Ness AR Systematic review of published trials on the effects of $n-3$ longchain polyunsaturated fatty acids on depressed mood, 76A.

Arcella D, Le Donne C \& Leclercq C Dietary exposure to chemicals within the process of risk assessment: possible applications to substances that may cause allergic reactions, DOI: 10.1079/PNS2005451, 418.

Arch JRS see Stocker CJ, 143

Arch JRS Central regulation of energy balance: inputs, outputs and leptin resistance, DOI: 10.1079/PNS2004407, 39.

Armah CK, James L, Doman I \& Minihane AM Meal fatty acid composition and postprandial vascular reactivity, 77A.

Armstrong F \& Clapham ME How do packed lunches of 7-10-year-old primary school children compare with Scottish nutritional standards for school meals? 61A.

Avenell A, Milne AC \& Stephen AI for the MAVIS Trial Group $A$ randomised double-blind, placebo-controlled trial of the effect of vitamin and mineral supplements on morbidity from infections in men and women aged 65 years and over, $24 \mathrm{~A}$

Bailey M, Haverson K, Inman C, Harris C, Jones P, Corfield G, Miller B \& Stokes $\mathrm{C}$ The development of the mucosal immune system pre-and postweaning: balancing regulatory and effector function, DOI: 10.1079/ PNS2005452, 451.

Barker ME, Hussain SA, Russell JM \& Stookey JD Water intake and risk of breast cancer: a case-control study, 100A.

Barnes MS, Robson PJ, Bonham MP, Strain JJ \& Wallace JMW Effect of vitamin $D$ supplementation on vitamin $D$ status and bone turnover in young adults, 37A.

Bartness TJ, Song CK, Shi H, Bowers RR \& Foster MT Brain-adipose tissue cross talk, DOI: 10.1079/PNS2004409, 53.

Barton KL, Anderson AS, Wrieden WL \& Baxter R Validity and reliability of a short questionnaire for assessing impact of cooking skills interventions, 101A.

Barton KL, Thomson C, Burrows E, Reid L, Anderson AS, Lietz G \& Longbottom PJ Reported fruit and vegetable intake of 50 children aged 11-13 in Dundee, Scotland, 27A.

Barton KL, Wrieden WL, Devlin E, Macaskill S, Lawrence JM \& Raats $\mathrm{M}$ The impact of 'CookWell' on assisting dietary change in Asian young women at risk of having low birth-weight babies: qualitative findings, 27A.

Bassil M, Hwalla N \& Obeid OA The acute effect of leptin injection on in vivo postprandial glycogen and lipid synthesis in rats, 74A.

Basten GP, Duthie SJ, Pirie L, Vaughan N, Hill MH \& Powers HJ Folate supplementation decreases lymphocyte uracil misincorporation into DNA in healthy volunteers, 68A

Baxter G, Paterson J, Wiles A, Graham A \& Shirastava R Salicylic acid: the spice of life: a pilot study, 64A.

Baxter JP, Fayers PM \& McKinlay AW A review of the quality of life of patients receiving parenteral nutrition at home, $13 \mathrm{~A}$.
Baxter JP \& McKee RF Are the Scottish Home Parenteral Nutrition Managed Clinical Network standards being met? 21A.

Bayes J, Lee M, Nightingale JMD, Smedley F, Wheatley C, Harrison L, Simmonett G, Hartt C \& Wilson D Home parenteral nutrition and catheter occlusion. A survey by the Looking into the Requirements for Equipment (LITRE) committee, 19A.

Begum G, Cunliffe A, Leveritt M, Esgate A, Franklin M \& Chowdrey $\mathrm{C}$ Effect of basic and advanced formulation carbohydrate-electrolyte drinks on physical and mental performance during high-intensity intermittent exercise, 52A.

Berry SEE \& Sanders TAB Influence of triacylglycerol structure of stearic acid-rich fats on postprandial lipaemia, DOI: 10.1079/PNS2005422, 205.

Berry SEE, Miller GJ \& Sanders TAB Influence of palmitic acid-rich triacylglycerols on postprandial activation of factor VII, 76A.

Bloom SR see le Roux CW, 213.

Boddy LM, Hackett AF, Stratton G, Taylor SR \& Lamb E A comparison of three methods of defining obesity in children using BMI cut-offs, 56A.

Boden M, Dadswell R \& Hattersley S Review of statutory and voluntary labelling of food allergens, DOI: 10.1079/PNS2005453, 475.

Boley R, Hart $\mathrm{K} \&$ Truby $\mathrm{H}$ A randomised trial investigating the effects of a low-carbohydrate weight-loss regimen on cardiovascular risk factors in men, 51A.

Bonnett AL, Procter KL, Gossiel F, Harrison CA, Barker ME \& Blumsohn A The effect of frequent feeding on bone turnover in human subjects, $93 \mathrm{~A}$

Boonsong T, Tsintzas K, Bennett A \& MacDonald I Effect of $48 \mathrm{~h}$ fasting upon skeletal muscle sterol regulatory element-binding protein-1c (SREBP1c) and carbohydrate responsive element-binding protein (ChREBP) expression in human subjects, $72 \mathrm{~A}$

Bowers RR see Bartness TJ, 53.

Boyd A, McCann M, Hashim Y, Haldar S, Gill C \& Rowland I Effects of watercress on biomarkers for colon cancer, $41 \mathrm{~A}$.

Brooker JD see Acamovic T, 403.

Brough L \& Rees G Changes in iron status throughout pregnancy in an ethnically diverse population, $83 \mathrm{~A}$

Buckley LE, Belshaw NJ \& Johnson IT The effects of dietary folate on methylation of the ESR1 CPG-island in a rat model of colorectal neoplasia, $69 \mathrm{~A}$

Bullock NR, Dainty JR, Hart D, Finglas P \& Powers HJ The bioavailability of riboflavin from foods, 86A.

Burdge GC see Tricon S, 171

Burke SJ, McCarthy SN, O’Neill JL \& Gibney MJ Where are Irish children eating? 36A

Buttriss J \& Nugent A LIPGENE: an integrated approach to tackling the metabolic syndrome, DOI: 10.1079/PNS2005441, 345.

Calder PC see Tricon S, 171

Cameron EAB, McGovern J, Hindle L, Miller C \& Fellows IW Percutaneous endoscopic gastrostomy insertion - can current antibiotic prophylaxis guidelines be effective? 4A.

Caresta E, Pierro A, Chowdhury M, Peters MJ, Petros AJ, Piastra M \& Eaton $\mathrm{S}$ Intravenous lipid utilisation in infants and children with sepsis and systemic inflammatory response syndrome, $6 \mathrm{~A}$.

Carpenter R, O'Callaghan YC, O'Grady M, Kerry JP \& O'Brien NM Modulatory effects of resveratol, citroflavan-3-ol and plant-derived extracts on oxidative stress in U937 cells, 42A

Carter L, Chowdhury S, Weekes CE \& Emery PW Barriers to the use of a nutrition screening tool, $12 \mathrm{~A}$.

Caterson I see Gill T, 255. 
Catterick J, Gannon RHT, Lovell D, MacDonald HM, Millward DJ \& New SA Sources of dietary alkali in the UK diet: potential renal acid load (PRAL) of commonly consumed hot and cold beverages, 93A.

Cawthorne MA see Stocker CJ, 143.

Chen L, Sanders TAB \& Berry SEE The bioavailability of stearic acid-rich triacylglycerol from shea butter, 77A.

Chopra M, Cooper K, Cossor F, Kayani N \& Thurnham DI Effect of dietary fat and fibre on the bioavailability of lycopene from tomato soup, $88 \mathrm{~A}$.

Chowdhury M, Eaton S, Peters MJ, Klein NJ, Goldman A \& Pierro A Promotion of monocyte HLA-DR expression and attenuation of cytokine response by glutamine supplementation in septic children, 16A.

Clegg M \& Shafat A Gastrointestinal transit of high-fat meals in obese humans, 37A.

Clément K Genetics of human obesity, DOI: 10.1079/PNS2005416, 133.

Connolly G, Cunningham R, Woodside JV, Young IS \& Maxwell AP Antioxidant vitamin concentrations and survival in a renal transplant population, $45 \mathrm{~A}$

Cook Z, Kirk S, Lawrenson S \& Sandford S Use of BMI in the assessment of undernutrition in older subjects: reflecting on practice, DOI: 10.1079 / PNS2005437, 313.

Corfield G see Bailey M, 451.

Costain L \& Croker H Helping individuals to help themselves, DOI: 10.1079/ PNS2004413, 89.

Costar A see Dickinson A, 269.

Coxhead JM, Bal W, Shenton BK, Williams EA \& Mathers JC Effect of butyrate on induction of aneuploidy in colorectal carcinoma cell lines, 70A

Craig LCA, Love J, Ratcliffe B \& McNeill G The relationship between overweight and lifestyle factors in children from the National Diet and Nutrition Survey: young people aged 4-18 years, 53A.

Craigie AM, Adamson AJ, Lake AA, Gibbons M, Wood C, Matthews JNS, Rugg-Gunn AJ \& Mathers JC Lifecourse influences on nutrient intake in adulthood, 59A.

Crevel R Industrial dimensions of food allergy, DOI: 10.1079/PNS2005454, 470.

Croker H see Costain L, 89.

Culkin A, Gabe S, Bjarnasson I, Grimble G \& Forbes A A double-blind randomised, controlled cross-over trial of glutamine supplementation in home parenteral nutrition, $5 \mathrm{~A}$.

Culverwell T The parent's perspective, DOI: 10.1079/PNS2005450, 339.

Cummings JH see McGough N, 434.

Cummins P, Armstrong R, Newby D, Wilson R \& Davidson I The efficacy of low-dose folic acid supplementation on endothelial function using pulse wave analysis, 84A.

Cummins P, Armstrong R, Newby D, Wilson R \& Davidson I The efficacy of low-dose folic acid supplementation on the percentage of circulating platelets ex vivo in healthy and dyslipidaemic men, 89A.

Curno R, Magee EAM, Edmond LM, Tasker SM \& Cummings JH Development of a novel biomarker of dietary inorganic sulfur intake, 28A

Curran K, Boylan SM, Cade JE \& Kirk SFL Validation of the caffeine assessment tool, $101 \mathrm{~A}$.

Dadswell R see Boden M, 475.

Danielzik S see Müller MJ, 249.

Davies HV GM organisms and the EU regulatory environment: allergenicity as a risk component, DOI: 10.1079/PNS2005462, 481.

Day MJ The canine model of dietary hypersensitivity, DOI: 10.1079/ PNS2005455, 458.

De Wagt A see Thurnham DI, 502.

Dearman RJ \& Kimber I Characterisation of immune responses to food allergens in mice, DOI: 10.1079/PNS2005456, 426

Dickinson A, Welch C, Ager L \& Costar A Hospital mealtimes: action research for change? DOI: 10.1079/PNS2005432, 269.

Ditchburn L \& Chapman W Developing a percutaneous endoscopic gastrostomy care pathway: a primary and secondary care collaboration, $22 \mathrm{~A}$.

Djazayery A, Keshavarz SA, Ansari F \& Mahmoudi M Socio-economic factors affecting the quantity and quality of dietary iron among rural women, 33A.
Dunlop H \& Lennie S General practitioners' prescribing practices for children with cows' milk allergy or intolerance, 98A.

Earland $\mathrm{J}$ A qualitative study on the main determinants of job satisfaction for postgraduate nutritionists, 97A.

Edington J, Knight H, Girod I, Saleh A \& Pang F Enteral feeding in the community: a study of health economic outcomes, 13A.

Efstathiou A \& Maxwell SM A comparison of the macronutrient intake of British adults in Liverpool and Cypriot adults in Paphos, Cyprus, 58A.

Ekelund U see Wareham NJ, 229.

Elgass S, Cooper A \& Chopra M The combined effect of flavonoids and epirubicin on in vitro proliferation of bladder cancer cells, 71A.

Elia M \& Stratton RJ Geographic inequalities in antioxidant nutrient status among older individuals in England, 15A.

Elia M \& Stratton RJ Poorer vitamin status in the elderly at risk of malnutrition using the 'Malnutrition Universal Screening Tool'? 15A.

Elmes MJ, Gardner DS \& Langley-Evans SC Prenatally programmed hypertension and its effects on the left ventricular pressure (LVP) function of the rat heart following ischaemia reperfusion, 82A

Englyst KN, Quigley ME \& Englyst HN A method for characterising carbohydrate bioavailability of fruit and vegetables, 88A.

Erhuma AM, Sculley D, Plant R, Salter AM, Langley-Evans SC \& Bennett $\mathrm{AJ}$ Exposure to a maternal low-protein diet in pregnancy programmes altered expression of sterol regulatory element-binding protein- $1 c$ and carbohydrate responsive element-binding protein in the offspring, $81 \mathrm{~A}$.

Fallon UB, Bury G, Daly S, Hannon F, Loftus BG, Morrison J, Murphy AW, Murrin CM, Nolan G, O'Mahony D \& Kelleher CC Planned pregnancy is no guarantee of folic acid compliance, $40 \mathrm{~A}$.

Finley W see Fry J, 359.

Foley CMMB, Wong C, Forbes A \& Gabe SM A comparison of malnutrition screening tools in acute hospital admissions to a district general hospital, $3 \mathrm{~A}$.

Forster SE, Gariballa SE \& Powers HJ Function-enabling diet (FED) study a randomised, double-blind, placebo-controlled trial of the effects of energy, protein and micronutrient supplementation of hospitalised elderly patients, $25 \mathrm{~A}$

Foster E, Matthews JNS, Mathers JC, Moynihan PJ \& Adamson AJ Packaged food intake by children aged 0 to 16 years ( $\mathrm{g} / \mathrm{kg}$ body weight), 63A.

Foster MT see Bartness TJ, 53.

Frayn KN Obesity and metabolic disease: is adipose tissue the culprit? DOI: 10.1079/PNS2004403, 7.

Fry $\mathrm{J} \&$ Finley $\mathrm{W}$ The prevalence and costs of obesity in the $E U$, DOI: 10.1079/PNS2005443, 359.

Fujiwara T, Davidson HIM \& Richardson RA Predicting energy expenditure from arm anthropometry, $5 \mathrm{~A}$.

Fuller Z, Botting NP, Morrison JJ, Botting C \& Duncan AJ Use of stable isotopically labelled compounds to investigate the digestive fate of glucosinolates in brassica vegetables, 86A.

Furrie E Probiotics and allergy, DOI: 10.1079/PNS2005466, 465.

Gannon RHT, Hannon EM, New SA \& Flynn A Estimation of net acid excretion indirectly $\left(N A E_{\text {ind }}\right)$ and net endogenous non-carbonic acid production (NEAP) in the Irish population: analysis of the North-South Ireland Food Consumption Survey (NSIFCS), 79A.

Gasper AV, Al Janobi A, Smith JA, Bacon J, Taylor MA, Hawkey CJ, Barrett DA, Fortun P, Atherton C \& Mithen RF Diet-gene interactions: broccol consumption and cancer prevention, $65 \mathrm{~A}$.

Genton L, van Gemert W, Pichard C \& Soeters P Physiological functions should be considered as true end points of nutritional intervention studies, DOI: 10.1079/PNS2005434, 285.

Gibbs M, Tzung C, Gatwood E, Hurley J \& Morgan L Dietary intake and determinants of food choice in post office shift-workers, 64A.

Gibney MJ see Roche HM, 371.

Gilchrist SECM, Woodside JV, Chakravarthy U \& Young IS, on behalf of the EUREYE investigators Frequency of fruit and vegetable consumption and carotenoid status in the EUREYE study, 46A.

Gill T, King L \& Caterson I Obesity prevention: necessary and possible. A structured approach for effective planning, DOI: 10.1079/PNS2005425, 255 . 
Ginty F, Prynne CJ, Muniz-Terrera G, Mishra GD, Prentice A \& O’Connell MA No evidence for a negative association between bone mineral status and indirect estimates of renal net acid excretion in adolescents, 80A.

Givens DI The role of animal nutrition in improving the nutritive value of animal-derived foods in relation to chronic disease, DOI: 10.1079/ PNS2005448, 395.

Goyal A, Chopra M, Delves G \& Cooper A Do prostasomes play a role in lycopene delivery? $94 \mathrm{~A}$

Goyal A, Hart-Prieto C, Stone N, Chopra M \& Cooper A Using Raman microspectroscopy to detect lycopene uptake into prostate cancer cells in vitro, $71 \mathrm{~A}$.

Graydon R, Woodside JV, Young IS \& Chakravarthy U Adhesion molecules and age-related macular degeneration, 46A.

Greaves E, Eastwood JA, Calder J, Silcock J \& Wright MJ Minimising the risk of hyperglycaemia induced by intradialytic parenteral nutrition, 18A

Haji Faraji M \& Leeds AR The effect of the high-and low-glycaemic index diets on urinary chromium in healthy individuals (a cross-over study), 48A

Hall NJ, Peters M, Eaton S \& Pierro A Association of hyperglycaemia with increased morbidity and mortality in neonates with necrotising enterocolitis, $7 \mathrm{~A}$.

Hall WL see Shaw DI, 349.

Hardcastle AC, Kyle JAM, Duthie G, McNeill G, Reid DM \& MacDonald HM Dietary flavonoid intakes in early postmenopausal Scottish women, $85 \mathrm{~A}$.

Harman NL, Tzung CW, Hampton SM \& Morgan LM Postprandial metabolic responses to a low-fat low-glycaemic index diet in a simulated shiftwork environment, 73A.

Harris C see Bailey M, 451.

Harwood SJ The impact of a nutrition support team on the prescribing of parenteral nutrition, $17 \mathrm{~A}$.

Hattersley S see Boden M, 475.

Haughton EL, Clifford MN \& Sharp PA Mechanisms involved in benzoic acid absorption by human intestinal epithelial cells, 87A.

Hauner H Secretory factors from human adipose tissue and their functional role, DOI: 10.1079/PNS2005428, 163.

Haverson K see Bailey M, 451.

Heird WC Biochemical homeostasis and body growth are reliable end points in clinical nutrition trials, DOI: 10.1079/PNS2005435, 297.

Hill MH, Mathers JC, Williams EA, Spiers A, Duckworth Y, Welfare M \& Powers HJ Colon mucosal folate is responsive to folic acid supplements and correlates with plasma folate, 90A.

Hill TR, Cotter AA, Wallace J, Robson PJ, Boreham C, Dubitzky W, Murray L, Flynn A, Kiely M \& Cashman KD Vitamin D status of adolescents from the Northern Ireland Young Hearts Project: effects of age, sex and season, $38 \mathrm{~A}$.

Hindle L, McGovern J \& Fellows IW Home parenteral nutrition in Norfolk: can a spoke provide the service? 19A.

Hodkinson CF, Jewell VC, Kelly M, Coudray C, Gilmore WS, O'Connor JM, Strain JJ \& Wallace JMW Zinc status and immune function in a healthy older population aged 55-70 years: the Zenith study, 33A.

Holmes VA \& McCance DR Could antioxidant supplementation prevent pre-eclampsia? DOI: 10.1079/PNS2005469, 491.

Huizinga H see Upritchard JE, 379.

Iason $\mathrm{G}$ The role of plant secondary metabolites in mammalian herbivory: ecological perspectives, DOI: 10.1079/PNS2004415, 123.

Inman C see Bailey M, 451.

Irvine PA, Welch RW, Livingstone MBE, Robson PJ, McDwyer M \& O'Connor GH Effects of varying the volume of bread in a breakfast meal on satiety and subsequent intakes, 36A.

Jarvis S, Spiers A, Duckworth Y, Welfare M, Powers HJ, Mathers JC \& Williams EA Dietary characteristics of gastroenterology patients, 99A.

Jeanes YM, Reeves S, Catterick J, Bishop JA \& New SA Association between body weight and calcium intake in Surrey females aged 11-16 years, 89A.

Jebb SA, Siervo M, Bluck LJC, Dixon A \& Prentice AM Effects of stepwise overfeeding on abdominal fat deposition and insulin sensitivity in adult lean men, $72 \mathrm{~A}$.
Jebb SA Dietary strategies for the prevention of obesity, DOI: 10.1079/ PNS2005429, 217.

Jia X, McNeill G \& Avenell A The effect of micronutrients and fatty acids on age-associated cognitive decline in the elderly: a systematic review, 32A. Johnson DM \& Sharp PA The effects of pro-inflammatory cytokines on iron absorption by human intestinal epithelial cells, 91A.

Jones AR, Kuznesof S, Richardson DP \& Seal CJ Increased wholegrain food consumption and coronary heart disease risk factors: the CHEW-IT study, 53A.

Jones P see Bailey M, 451.

Joyce T, Hearty AP, McCarthy SN \& Gibney MJ Analysis of the relationship between frequency of consumption of non-milk extrinsic sugar meals and percentage total energy from non-milk extrinsic sugars in a representative sample of Irish adults, 49A.

Jukes AL, Hawthorne AB, Wright JB, Abdoolla AM \& Harwood SJ Impact of the nutrition support team on parenteral nutrition over 5 years, $11 \mathrm{~A}$

Kato A, Kurihara M, Sasaki M \& Forbes A Comparison of dietary characteristics in patients with Crohn's disease between UK and Japan, 18 A.

Kelly FJ Vitamins and respiratory disease: antioxidant micronutrients in pulmonary health and disease, DOI: 10.1079/PNS2005457, 510.

Kerr MA, McNulty H, Scott JM, Molloy AM, Ward M, Sullivan N, Putland C \& Livingstone MBE Investigation of $B$ vitamin status in lean and obese women: a pilot study, 39A.

Kiely M, Hannon EM, Walton J \& Flynn A Vitamin D intakes in Irish 5-12-year-old schoolchildren, 38A.

Kimber I see Dearman RJ, 426.

King L see Gill T, 255.

Kirk S see Cook Z, 313.

Kirkwood L, Aldujaili E \& Drummond S Reduced energy intake or increased physical activity? Effective weight-loss strategies for women, $57 \mathrm{~A}$.

Kopelman PG Clinical treatment of obesity: are drugs and surgery the answer? DOI: 10.1079/PNS2004410, 65.

Koretz RL Death, morbidity and economics are the only end points for trials, DOI: 10.1079/PNS2005433, 277.

Kromhout D see Woodside JV, 554.

Kyle JAM, Sharp L, Duthie GG \& McNeill G Possible protective effect of dietary flavonoids in colorectal cancer: a case-control study, 66A.

Lawrenson S see Cook Z, 313.

Le Donne C see Arcella D, 418

Leclercq C see Arcella D, 418.

le Roux CW \& Bloom SR Peptide YY, appetite and food intake, DOI: 10.1079/PNS2005427, 213.

Lightowler HJ, Henry CJK, Warren JM \& Richardson DP The use of readyto-eat breakfast cereals as a meal substitute for weight loss - the impact of variety, 52A.

Lilley C \& Langley-Evans SC Fetal programming of adult disease may be induced by oxidative damage and alterations in antioxidant activity, $81 \mathrm{~A}$.

Lin CI, Wong MCY, Whitehead NJ, Preedy VR \& Wiseman $\mathrm{H}$ The application of 'Lab-on-a-Chip ${ }^{\circledR}$, for proteomic studies in screening metabolic perturbations, 95A.

Lindström J, Peltonen M \& Tuomilehto J Lifestyle strategies for weight control: experience from the Finnish Diabetes Prevention Study, DOI: 10.1079/PNS2004412, 81.

Livesey G Low-glycaemic diets and health: implications for obesity, DOI: 10.1079/PNS2004400, 105.

Logan CM, Wallace JMW, Robson PJ, Bonham MP, Rennie KL \& Livingstone MBE The effects of commercial weight-loss diets on body weight and body composition during weight-loss and follow-up phases, 35A.

Lordan S, O'Callaghan YC \& O'Brien NM An investigation of the antiapoptotic efficiency of apigenin, astaxanthin and lycopene in cholesterol oxide-treated human monocytic blood cells, 42A.

Low Y-L, Taylor J, Grace P, Mulligan A \& Bingham S Prospective phytooestrogen exposure as assessed using four methods and their relationship to prostate cancer risk in the EPIC-Norfolk cohort, 65A. 
Lynn A, Fuller Z, Hillman K \& Ratcliffe B Broccoli consumption has no effect on xenobiotic metabolising enzymes, 66A.

McAtear C Weighing hospital patients, Quality Improvement Scotland standards and the Malnutrition Universal Screening Tool, 10A.

McCall D see Woodside JV, 543.

McCance DR see Holmes VA, 491.

McCaughey LP, Frear L, Whitham C, Thomas J \& Cade JE Can peer education empower individuals from low-income backgrounds with diabetes? 98A

MacDonald HM, Hardcastle AC, Sandison R, New SA \& Reid DM Dietary checklist detects increased fruit consumption as part of a fruit and vegetable intervention trial, $60 \mathrm{~A}$.

McGartland C see Woodside JV, 543.

McGough N \& Cummings JH Coeliac disease: a diverse clinical syndrome caused by intolerance of wheat, barley and rye, DOI: 10.1079/PNS2005461, 434.

McGovern J, Beales ILP \& Fellows IW A pilot study of the effect of nasa mupirocin, before percutaneous endoscopic gastrostomy, upon peristomal colonisation and infection, 14A

McHattie G Practice and problems with gastrostomies, DOI: 10.1079/ PNS2005440, 335.

McHoney M, Carnielli VP, Eaton S, Howard R, Kiely EM, Drake DP, Spitz L, \& Pierro A Differential effects of laparoscopic and open surgery on postoperative protein metabolism, 10A.

McKeeman GC, Woodside JV, Yarnell JWG, Young IS \& Evans A B vitamin and antioxidant supplementation has no effect on $C$-reactive protein concentration in healthy male volunteers, 47A.

McMullen S \& Langley-Evans SC Sex-specific up regulation of angiotensin II receptor $\left(A T_{2} R\right)$ mRNA expression in hypertensive rats exposed to a lowprotein diet in utero, $82 \mathrm{~A}$.

Mackinnon LJ, Blake A, Ritchie MR \& Riches AC Isoflavone content of soya-based beverages and desserts, 28A.

Madigan SM, Gamble D, McClean C, Brown J, Trinick T, Duly E \& Davison GW The consumption of a commercially available sports drink on the effectiveness of intermittent exercise, 45A.

Madigan SM, Stevenson M, Wright ME, Fleming P, Dobbs F \& McAuley $\mathrm{D}$ A randomised controlled trial of a pragmatic nutrition education intervention in primary care, $34 \mathrm{~A}$

Madsen C Prevalence of food allergy: an overview, DOI: 10.1079/ PNS2005458, 413.

Manaf ZA \& Moynihan PJ An investigation into schoolchildren's knowledge and awareness of diet and dental health, 61A.

Maryon-Davis A Weight management in primary care: how can it be made more effective? DOI: 10.1079/PNS2004414, 97.

Masson LF, Sharp L, Little J, Brockton NT, Cotton SC, Haites NE \& Cassidy $\mathrm{J}$ Does genetic variation modify associations between meat intake and colorectal cancer: results from a population-based, case-control study in North-East Scotland, 54A.

Mburu ASW see Thurnham DI, 502.

Meredith C Allergenic potential of novel foods, DOI: 10.1079/PNS2005463, 487.

Miller B see Bailey M, 451.

Milne AC, Avenell A \& McNeill G for the MAVIS Trial Group Effect of vitamin and mineral supplementation on cognitive function in men and women aged 65 years and over, $31 \mathrm{~A}$.

Mishra GD, O'Connell MA, Prynne CJ, McNaughton SA \& Kuh D Childhood and adult dietary vitamins $B_{1}$ and $B_{12}$ intake and psychiatric symptom frequency at age 43 among women in the 1946 British Birth Cohort, 31A.

Mohamed HJ, Bruggraber SFA, Geissler CA \& Powell JJ Hepcidin prohormone ELISA kit: a reproducibility study, 84A.

Moloney F, Noone E, Gibney MJ \& Roche HM Improvement in insulin sensitivity following a cis-9, trans-11 conjugated linoleic acid (CLA)enriched diet is associated with an improvement in inflammatory profile in adipose tissue, 44A.

Monro J Expressing the glycaemic potency of foods, DOI: 10.1079/ PNS2004401, 115.

Mooney KM, Young IS \& Cuskelly GJ The effect of folate, pyridoxine and riboflavin depletion on plasma homocysteine, $47 \mathrm{~A}$.

Moore SE see Prentice AM, 153.
Moynihan $\mathrm{P}$ The interrelationship between diet and oral health, DOI: 10.1079/PNS2005431, 571.

Mrayati M, Hwalla N \& Obeid OA No acute effect of ghrelin injection on in vivo postprandial glycogen and lipid synthesis of rats, 74A.

Mullen A, Weldon SM, Loscher CE \& Roche HM Anti-inflammatory effects of eicosapentaenoic and docosahexaenoic acid on classically activated human THP1 monocyte-derived macrophages, 43A.

Müller MJ, Danielzik S \& Pust S School-and family-based interventions to prevent overweight in children, DOI: 10.1079/PNS2005424, 249.

Mulrooney LJ, Bagley JS, Wilkinson JA, Kelty C, Coker AO \& Jacob $\mathrm{G}$ Nasojejunal feeding does not improve clinical outcomes and is poorly tolerated following colorectal surgery, 9A.

Murphy EF, Hooiveld GJEJ, Muller M \& Cashman KD Effect of conjugated linoleic acid on global gene expression in human intestinal-like Caco-2 cells, 43A.

Murphy PM, Rahamin J, Wheatley T, McQuarrie S \& Lewis SJ An investigation into the peri-operative nutritional management of upper gastrointestinal carcinoma in major cancer centres, 8A.

Murray CDR, Gouveia C, Le Roux C, Ghatei M, Emmanuel AV \& Gabe SM The effects of different macronutrient infusions on appetite, satiety and ghrelin levels in parenterally fed patients, 6A.

Murrin CM, Bury G, Daly S, Fallon U, Hannon F, Loftus BG, Morrison J, Murphy A, Nolan G, O'Mahony D \& Kelleher CC Alcohol consumption in pregnant Irish women, 49A.

Mwaniki DL see Thurnham DI, 502.

Napier JA \& Sayanova O The production of very-long-chain PUFA biosynthesis in transgenic plants: towards a sustainable source of fish oils, DOI: 10.1079/PNS2005447, 387.

Nicholas JL, Berry SEE, Mulla U, Kelly FJ \& Sanders TAB Urinary potassium excretion and plasma ascorbic acid concentration as biomarkers of increased intake of fruit and vegetable intake, 54A.

Nooyens AJ see Seidell JC, 1.

Nugent A see Buttriss J, 345.

O'Connell MA, Mishra GD, McNaughton SA, Prynne CJ \& Kuh D Intakes of antioxidants in childhood and the risk of psychiatric disorder in females between ages 15 to 32 in the 1946 British Birth Cohort, 32A.

O'Halloran J, Clegg M, Brennan G, Foley M, Murphy B, O'Sullivan A \& Shafat A High-concentration sports drinks aid performance, 44A.

O'Neill JL, McCarthy SN, Burke SJ \& Gibney MJ Prevalence of obesity in Irish children, $35 \mathrm{~A}$.

Ogborne RM, Rushworth SA, Harvey GD, Schippers JC \& O'Connell MA Effect of dietary antioxidants on glutamate cysteine ligase modulator sub-unit gene expression in human THP-1 monocytic cells, 67A.

Oyston C, Ransley JK, Thomas JD \& Cade JE Validation of the integral costing of DANTE - Diet and Nutrition a Tool for Evaluation, 102A.

Page KB, Maden KE, Morley SR \& McAlindon ME The home parenteral nutrition service for adults in Sheffield, 23A.

Page KB, Maden KE, Morley SR \& McAlindon ME Without hope? Home parenteral nutrition and malignant disease in Sheffield, 24A.

Panteli JV, Crook MA, Horn V \& O'Donohue J The importance of the refeeding syndrome, $21 \mathrm{~A}$.

Parkinson EJ, Lawrence KM, Latchman DS, Eaton S \& Pierro A Modulation by hypothermia of hepatic gene expression following intestinal ischaemiareperfusion, $22 \mathrm{~A}$.

Paterson E, Carson-Long J, Gordon M \& Lovegrove J Dietary selenium intake and plasma glutathione peroxidase status in healthy British adults, 92A.

Peltonen M see Lindström J, 81.

Phillips C see Roche HM, 371.

Pichard C see Genton L, 285.

Powell-Tuck $\mathrm{J}$ The management of short-term intestinal failure in obese patients, DOI: 10.1079/PNS2004426, 263.

Prentice AM, Rayco-Solon P \& Moore SE Insights from the developing world: thrifty genotypes and thrifty phenotypes, DOI: 10.1079/PNS2005421, 153.

Prynne CJ, Mishra GD, O’Connell MA, Muniz G, Prentice A \& Ginty $\mathrm{F}$ Fruit and vegetable consumption and bone mineral status in adolescents, 92A. 
Prynne CJ, Paul AA, Key RK, Jarjou LMA \& Goldberg GR Iron intakes of rural Gambian women and children, 90A.

Puglia FA \& Henry CJK Influence of different high-protein meals on subsequent food intake, 51A.

Pust S see Müller MJ, 249.

Qatatsheh A, Seal CJ, Welfare MR \& Hesketh JE Patients with ulcerative colitis show an altered frequency distribution of a single novel polymorphism (SNP) in the gene encoding the phospholipid hydroperoxide glutathione peroxidase 4 (GPX4), 20A.

Ransley JK, Cade JE, Greenwood DC, Blenkinsop S, Schagen S, Schagen I, Teeman D, White $\mathrm{G} \&$ Scott $\mathrm{E}$ Assessing the impact of the National School Fruit and Vegetable Scheme on children's fruit, vegetable and nutrient intake, 62A.

Rayco-Solon P see Prentice AM, 153.

Rayman MP \& Goenaga Infante H Selenium-enriched yeast as a nutritional supplement: bioavailability, toxicology, efficacy and new identification of an anti-cancer component, $91 \mathrm{~A}$.

Rayman MP Selenium in cancer prevention: a review of the evidence and mechanism of action, DOI: 10.1079/PNS2005467, 527.

Reeves S, Jeanes Y, Catterick J, Bishop JA \& New SA Physical activity, dietary intake and dieting behaviours of Surrey females aged 11-16 years, $62 \mathrm{~A}$

Ricquier D Respiration uncoupling and metabolism in the control of energy expenditure, DOI: 10.1079/PNS2004408, 47.

Roche HM Fatty acids and the metabolic syndrome, DOI: 10.1079/ PNS2004405, 23

Roche HM, Phillips C \& Gibney MJ The metabolic syndrome: the crossroads of diet and genetics, DOI: 10.1079/PNS2005445, 371.

Rungapamestry V, Duncan AJ, Fuller Z \& Ratcliffe B The effect of processing of cabbage on myrosinase activity, glucosinolate concentrations and production of breakdown products, 67A.

Ryan E, Galvin K, O'Connor TP, Maguire AR, McCarthy F \& O'Brien $\mathrm{NM}$ Phytosterol, tocopherol and squalene content of five edible nuts (Brazil, pecan, pine, pistachio, cashew), 41A.

Ryan K, Major C, Lock AL, Bauman DE \& Salter AM Interactive effects of dietary cholesterol and inhibition of stearoyl $\mathrm{CoA}$ desaturase activity on lipogenic gene expression, 75A.

Samani D, Hawdon D \& McCarthy HD Prevalence of overweight and obesity in Afro-Caribbean schoolchildren in West London, 57A.

Sanders TAB see Berry SEE, 205.

Sanders TAB, Clode AJ, Lincoln LA \& Walker S Influence of ultraviolet- $B$ v. an increased dietary intake of cholecalciferol on serum 25-OH vitamin D concentrations, 79A.

Sandford S see Cook Z, 313.

Sayanova O see Napier JA, 387.

Sculley DV \& Langley-Evans SC Age-related loss of renal function is driven by programmed oxidative processes in the rat, 83A.

Searles K Audit of enteral feeding in the community - what's out there? 23A

Seidell JC, Nooyens AJ \& Visscher TLS Cost-effective measures to prevent obesity: epidemiological basis and appropriate target groups, DOI: 10.1079/PNS2004402, 1.

Seyoum TA \& Henry CJK The role of potassium on blood glucose - is glycaemic response sex-specific? 73A.

Seyoum TA, Henry CJK \& Lightowler HJ The role of zinc on glycaemic response, $55 \mathrm{~A}$

Shaw DI, Hall WL \& Williams CM Metabolic syndrome: what is it and what are the implications? DOI: 10.1079/PNS2005442, 349.

Sheikh-Ismail LI, Henry CJK, Lightowler HJ \& Musaiger AO The prevalence of obesity among females living in the United Arab Emirates, $56 \mathrm{~A}$.

Shi H see Bartness TJ, 53.

Sims HM, Major C, Lock AL, Bauman DE \& Salter AM Inhibition of stearoyl CoA desaturase activity induces hypercholesterolaemia in cholesterol-fed hamsters, 75A.

Singhal A Endothelial dysfunction: role in obesity-related disorders and the early origins of CVD, DOI: 10.1079/PNS2004404, 15.
Skidmore PML, Yarnell JWG, Stevenson MR, MacMahon J, Shields M \& Evans A Diet and asthma and atopy risk in Northern Irish primary school children, 99A.

Small M, Soulsby CT, Durman K, Hoyle L \& Powell-Tuck J Confirming gastric placement of nasogastric tubes in critically ill patients using $\mathrm{pH}$ measurements: is it feasible? 20A

Smith S, Davidson HIM \& Jenkins DAS Prediction of fat-free mass in longterm haemodialysis patients using dual X-ray absorptiometry (DXA) as the reference method, $2 \mathrm{~A}$.

Smith S, Jenkins DAS \& Davidson HIM Validity of nutritional assessment methods in long-term haemodialysis patients, 100A

Smith TK \& Johnson IT Effects of glucosinolate breakdown products on the cell-cycle in HT29 colorectal cancer cells, 69A

Smyth A, Cade JE \& Thomas J How much does what we eat cost? Validation of a new database approach to estimating food costs, 102A

Soeters P see Genton L, 285.

Somerset SM \& Johannot L Dynamics of flavonoid consumption in the Australian population, $85 \mathrm{~A}$

Song CK see Bartness TJ, 53.

Soulsby C, Yazaki E, Evans D \& Powell-tuck J Nasogastric feed infusion in healthy volunteers: can different methods of feed administration promote gastric emptying? 4A.

Spence M, Black RNA, Cuskelly GJ, Ennis CN, McCance DR, Young IS, Bell PM \& Hunter SJ High- v. low-sucrose diet: evaluation of effects on insulin sensitivity, 34A

Staehelin HB Micronutrients and Alzheimer's disease, DOI: 10.1079/ PNS2005459, 565.

Stefanutti G, Lister P, Smith V, Peters MJ, Klein NJ, Pierro A \& Eaton $\mathrm{S}$ Necrotising enterocolitis: role of P-selectin in the development of intestinal inflammation and histological injury, 7A.

Stefanutti G, Pierro A, Spitz L \& Eaton S Peroxynitrite decomposition catalyst FeTMPyP ameliorates intestinal and pulmonary organ injury in an infant animal model of intestinal ischaemia and reperfusion, 17A.

Stephen AI \& Avenell A Vitamin and mineral supplementation to reduce infection in adults: a systematic review, 14A.

Stewart-Knox BJ Psychological underpinnings of metabolic syndrome, DOI: 10.1079/PNS2005444, 363.

Stocker CJ, Arch JRS \& Cawthorne MA Fetal origins of insulin resistance and obesity, DOI: 10.1079/PNS2005417, 143.

Stokes C see Bailey M, 451.

Stratton RJ Elucidating effective ways to identify and treat malnutrition, DOI: 10.1079/PNS2005436, 305.

Stratton RJ Should food or supplements be used in the community for the treatment of disease-related malnutrition? DOI: 10.1079/PNS2005439, 325

Stratton RJ \& Elia M Geographic inequalities in malnutrition prevalence in the elderly across England, 12A

Stratton RJ \& Elia M Meta-analysis suggests post-operative enteral nutritional support reduces complication rates in patients undergoing gastrointestinal surgery, 9A.

Surujlal-Harry A, Rees GA, Bakhshi S \& Baker A Ethnic differences in fruit, vegetable and breakfast cereal consumption in girls aged 14-15 years, $63 \mathrm{~A}$

Sweeney MR, McPartlin J, Weir DG, Daly S, Pentieva K, Daly L \& Scott $\mathrm{JM}$ Folic acid consumption in pregnancy leads to the appearance of unmetabolised folic acid in cord-blood and in infants, 40A.

Synott K, Bogue J, Scott J, Amarri S, Benatti F, Frias D, Gil A, Uusijärvi A, Norrin E, Edwards CA \& other members of INFABIO project Knowledge and attitudes of parents of young children in four European countries about food allergy and health, 29A.

Thane CW, Jones AR, Stephen AM, Seal CJ \& Jebb SA Secular trends in whole-grain intake and sources of British adults, 59A.

Thurnham DI, Mburu ASW, Mwaniki DL \& De Wagt A Micronutrients in childhood and the influence of subclinical inflammation, DOI: 10.1079/ PNS2005468, 502.

Tighe P, Ward M, McNulty H, Finnegan O, Strain JJ, Dunne A, Molloy AM \& Scott JM The impact of initial vitamin $B_{12}$ status on the extent of plasma homocysteine lowering with folic acid, 39A.

Trautwein EA see Upritchard JE, 379. 
Trayhurn P The biology of obesity, DOI: 10.1079/PNS2004406, 31.

Trebble TM Bone turnover and nutritional status in Crohn's disease: relationship to circulating mononuclear cell function and response to fish oil and antioxidants, DOI: 10.1079/PNS2005419, 183.

Tricon S, Burdge GC, Williams CM, Calder PC \& Yaqoob P The effects of conjugated linoleic acid on human health-related outcomes, DOI: 10.1079/ PNS2005418, 171.

Tuomilehto J see Lindström J, 81.

Turner P, Harper J, Breen A \& Shenkin A The importance of 24 h enteral feeding in achieving tight glycaemic control in critically patients, 8A.

Tyson J, Spiers A, Caple F, Hesketh JE \& Mathers JC Inter-individual variation in nucleotide excision repair capacity: potential scope for dietary modulation of DNA repair, 68A.

Upritchard JE, Zeelenberg MJ, Huizinga H, Verschuren PM \& Trautwein EA Modern fat technology: what is the potential for heart health? DOI: 10.1079/PNS2005446, 379.

van Gemert W see Genton L, 285.

van Sluijs EMF see Wareham NJ, 229.

Vassiliadou M, Olano-Martin E \& Minihane AM The impact of fish oil fatty acids on endothelial function: a series of cell culture experiments, 78A.

Vega R, Kalantzis CN, Georgios G, Lim W, Papadia C, Polymeros D, Forbes A \& Gabe SM Chronic cholestasis and home parenteral nutrition: how much lipid is it safe to give? 3A.

Verschuren PM see Upritchard JE, 379.

Visscher TLS see Seidell JC, 1.

Walker AW, Duncan SH, McWilliam Leitch EC \& Flint HJ Response of human colonic microbiota and butyrate formation in continuous culture to a one-unit $p H$ shift, 70A.

Wallace JMW, Keaveney E, Robson PJ, Sinclair AJ \& Kiely M Effect of $\gamma$-tocopherol supplementation on $\gamma$-tocopherol status in healthy adults, 48A

Ward N Nutrition support referrals for gastrointestinal surgery patients timely and appropriate? $11 \mathrm{~A}$.

Wardle $\mathrm{J}$ Understanding the aetiology of childhood obesity: implications for treatment, DOI: 10.1079/PNS2004411, 73.

Wareham NJ, van Sluijs EMF \& Ekelund U Physical activity and obesity prevention: a review of the current evidence, DOI: 10.1079/PNS2005423, 229

Weekes CE, Elia M \& Emery PW Tailored dietary advice and food fortification results in weight gain and clinical benefit in malnourished patients with chronic obstructive pulmonary disease (COPD), $2 \mathrm{~A}$.
Welch AA, Runswick SA, Mulligan AA, Khaw KT \& Bingham SA Relationship between dietary measures of potential renal acid load and urinary pH, 80A.

Welch C see Dickinson A, 269.

White C, De Looy A \& Drummond S The effect of weight loss and weight maintenance on quality of life, 58A.

Willett AM Vitamin D status and its relationship with parathyroid hormone and bone mineral status in older adolescents, DOI: 10.1079/PNS2005420, 193.

Williams CM see Shaw DI, 349.

Williams CM see Tricon S, 171.

Wong MCY, Hunter R, Srirajaskanthan R, Trick K, L'abbe MR, Preedy VR \& Wiseman $\mathrm{H}$ The effect of acute alcohol dosage on the perturbation of antioxidant capacity in the rat liver, 95A.

Wong MCY, Nakahara T, Hashimoto K, Hirano M, Duffy R, Radendram R, Preedy VR \& Wiseman $\mathrm{H}$ The mRNA levels of brain antioxidant enzymes are not altered by galactosamine-induced metabolic and oxidative stress, 96A.

Wong MCY, Nakahara T, Hashimoto K, Hirano M, Hunter R, Srirajaskanthan $\mathrm{R}$, Preedy VR \& Wiseman $\mathrm{H}$ The $m R N A$ levels of brain antioxidant enzymes in supplemental antioxidant therapy: a comparison of phytooestrogens and $\alpha$-tocopherol, 97A.

Wong MCY, Niemela O, Parkkila S, Rajendram R, Preedy VR \& Wiseman $\mathrm{H} \alpha$-Tocopherol does not ameliorate acute in vivo formation of malondialdehyde-protein adducts in liver and brain after D-galactosamine administration, 96A.

Wood A, Baxter G, Paterson J, Thies F \& Duthie G Comparison of methods to determine salicylic acid content of fruit juices, 87A.

Woodside JV \& Kromhout D Fatty acids and CHD, DOI: 10.1079/ PNS2005465, 554.

Woodside JV, McCall D, McGartland C \& Young IS Micronutrients: dietary intake v. supplement use, DOI: 10.1079/PNS2005464, 543.

Woodward RJ, Yeoh C, Sanders TAB \& Berry SEE Acute effects of randomised palm oil $\mathrm{v}$. high-oleic sunflower-seed oil on postprandial lipaemia, 78A.

Wrieden WL, Armstrong J, Barton KL \& Peace H A comparison of various existing surveys on food consumption in Scotland and their usefulness in measuring the Scottish dietary targets, 60A.

Yaqoob P see Tricon S, 171.

Young IS see Woodside JV, 543.

Zeelenberg MJ see Upritchard JE, 379. 